\title{
Effect of washing conditions on the recovery of milk fat globule membrane proteins during the isolation of milk fat globule membrane from milk
}

\author{
T. T. Le, ${ }^{* 1}$ J. Van Camp,${ }^{*} \dagger$ R. Rombaut, ${ }^{*}$ F. van Leeckwyck, ${ }^{*}$ and K. Dewettinck* \\ *Department of Food Safety and Food Quality, Faculty of Bioscience Engineering, Ghent University, Belgium \\ †Department of Bioscience Engineering, University of Antwerp, Belgium
}

\begin{abstract}
During the isolation of milk fat globule membrane (MFGM) from milk, washing is considered the most critical stage in which loss of MFGM components occurs. In this study, using a cream separator, the influence of washing on the recovery of MFGM proteins was investigated. The residue of non-MFGM proteins in the MFGM material obtained after washing was quantitatively determined using densitometric analysis of one-dimensional sodium dodecyl sulfate-PAGE after silver staining of the gel. Using deionized water as the washing solution did not increase the loss of MFGM proteins compared with other common salt solutions in terms of recovery of MFGM proteins and contamination with non-MFGM proteins. The increase in wash temperature from 38 to $46^{\circ} \mathrm{C}$ did not show a significant decrease in yield of MFGM proteins because of variation between the experimental replicates. Coalescence of fat globules occurs during isolation. To increase MFGM purity while maintaining a high MFGM protein recovery, using larger volumes of wash solution is more advisable rather than increasing the number of washings from 2 to 3.
\end{abstract}

Key words: milk fat globule membrane protein, isolation, sodium dodecyl sulfate-PAGE, silver staining

\section{INTRODUCTION}

Fat globules in milk are covered by a film called the milk fat globule membrane (MFGM). This 10- to 20-nm-thick membrane has unique composition and properties and acts as a natural emulsion-stabilizing agent preventing flocculation and coalescence and protecting fat globules against enzyme attack as well as chemical reactions (oxidation). The natural MFGM consists of 3 distinct layers, viewed from the lipid

Received December 31, 2008.

Accepted April 17, 2009.

${ }^{1}$ Corresponding author: le.trungthien@ugent.be core outward - a monolayer of lipid droplet-associated proteins and polar lipids, an electron-dense proteinaceous coat, and finally a bilayer membrane of polar lipids and proteins (Keenan and Mather, 2006). As such, the MFGM comprises mainly membrane-specific glycoproteins and polar lipids including phospho- and sphingolipids. The lower the loss during isolation, the more representative is the MFGM material obtained compared with the natural MFGM in terms of composition and (emulsifying) functional properties.

For the washing method, the MFGM is generally isolated from milk through a 4-step process: separation of the fat globules, washing of cream, release of MFGM from the washed cream, and finally collection of the MFGM material (Mather, 2000). The first 2 steps can be carried out using a laboratory centrifuge or, on a larger scale, a bench-top cream separator. Large differences in type of washing solutions, washing temperature, number of washing steps, and volume of the washing solution used for each wash have been reported in literature (Dewettinck et al., 2008). Not all MFGM proteins are equally attached to the MFGM. Compared with the integral proteins, the loosely bound proteins such as mucin 1 (MUC1; Liu et al., 2005), xanthine oxidase (XO; Mather et al., 1977), periodic acid Schiff (PAS) 6/7 (Kanno and Kim, 1990), and MUCX (Liu et al., 2005) are more prone to losses during isolation. When using laboratory centrifuges, 3 washing steps are sufficient to remove virtually all milk serum components (Nejjar et al., 1986; Ye et al., 2004b), although these conditions already cause losses of MFGM components (Anderson and Brooker, 1974; Nejjar et al., 1986). With sensitive detection methods, some non-MFGM proteins are still observed after 3 successive washings of the cream; for example, BSA using electro-immuno diffusion against anti-BSA sera (Nejjar et al., 1986) and caseins, $\beta$-LG, and lactoferrin using sensitive silver staining (Fong et al., 2007).

Washing of cream is needed to remove caseins, whey proteins, and lactose, but this stage is also critical because it causes loss of MFGM components. The loss of MFGM material caused by washing during largescale isolation of MFGM using cream separators has 
not been described sufficiently to date. In this study, the recovery of MFGM proteins as a function of washing procedure, washing solution, washing temperature, number of washes, and volume of washing solutions was evaluated. This was based on both the amount of MFGM proteins recovered as well as contamination of protein in the MFGM isolate with caseins and whey proteins, which were quantitatively determined using a sensitive silver-staining method on SDS-PAGE gels.

\section{MATERIALS AND METHODS}

\section{Materials}

Raw milk was collected from a stirred cooling tank of a local farm within $2 \mathrm{~h}$ after morning milking. All chemicals used for chemical analysis were of $>99 \%$ purity and were purchased from Chem-Lab NV (Zedelgem, Belgium). Purified BSA, $\alpha_{S^{-}} \mathrm{CN}, \beta-\mathrm{CN}, \kappa-\mathrm{CN}$, $\beta-\mathrm{LG}$, and $\alpha-\mathrm{LA}$ were obtained from Sigma-Aldrich NV (Bornem, Belgium).

\section{Isolation of MFGM Material}

The MFGM material was isolated using the procedure illustrated in Figure 1. For each experimental run, $5 \mathrm{~L}$ of milk was used. Fat globules were first separated from the milk using a bench-top cream separator. The cream was then suspended in washing solution and held at the process temperature for $15 \mathrm{~min}$. The cream was subsequently re-separated. This washing step was repeated once or twice depending on the experiment. The separator was adjusted so that the fat content of the output cream of the first separation or following re-separation was between 36 and $40 \%$ and the input flow was slow to diminish the inclusion of air. After being chilled overnight in a fridge, the washed cream was churned using a KitchenAid mixer (KitchenAid, St. Joseph, MI). Buttermilk was collected by filtration through 2 layers of cheesecloth, which was used to retain minute butter granules. The butter obtained was melted at $60^{\circ} \mathrm{C}$ after adding the same amount of deionized water. The resulting slurry was centrifuged in glass tubes with a laboratory centrifuge (Martin Christ Osterode, Harz, Germany) at 1,070 $\times g$ for 5 min. The tubes were then immerged in ice to crystallize the fat, and the butter serum was collected through 2 layers of the cheesecloth. The powdered MFGM material was obtained after freeze drying of the pooled solution of buttermilk and butter serum (i.e., the MFGM suspension). The MFGM material and a sufficient amount of the MFGM suspension were stored at $-20^{\circ} \mathrm{C}$ before further analysis.

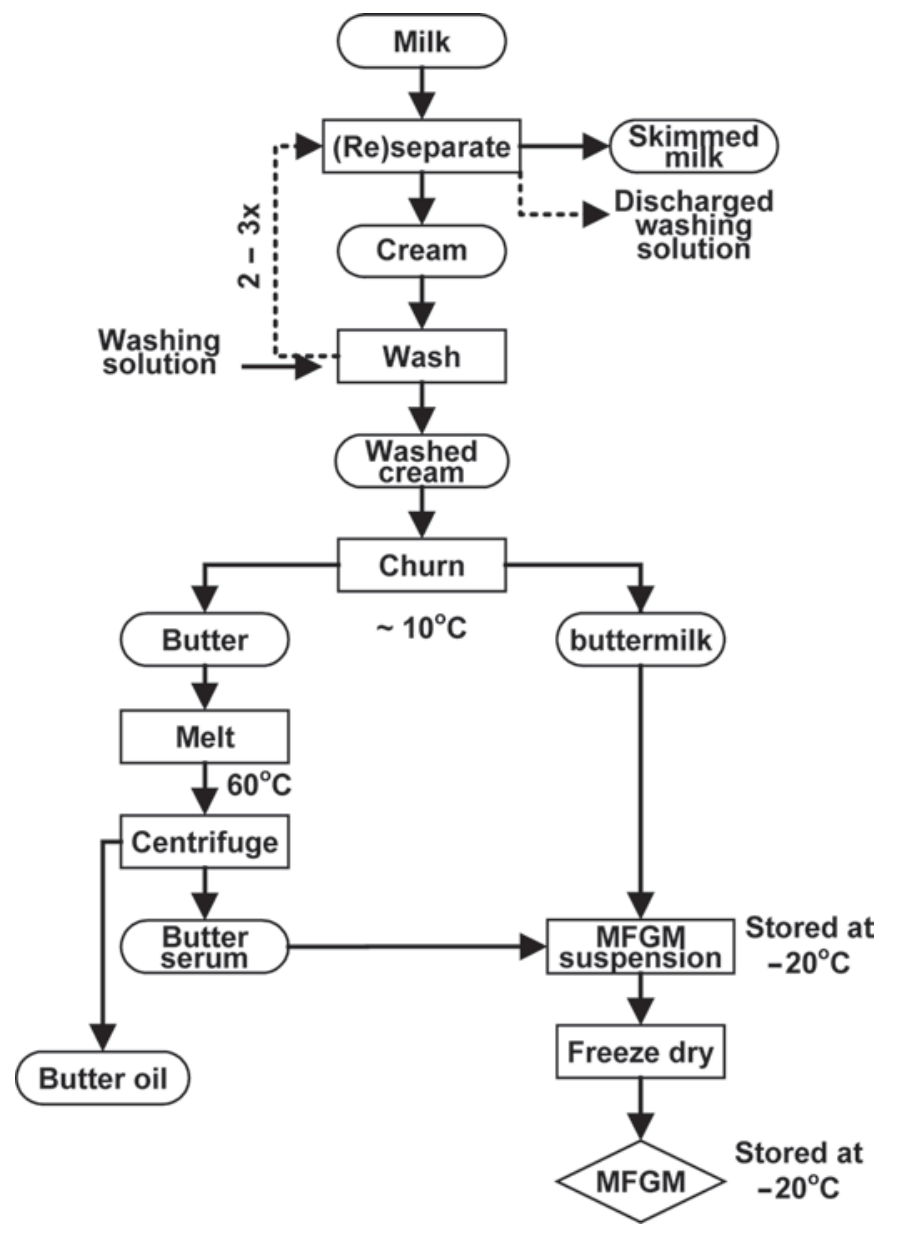

Figure 1. Experimental isolation procedure of milk fat globule membrane (MFGM) material from milk.

\section{Chemical Analyses}

The total protein content of the washed cream, the MFGM suspensions, and the MFGM powder was determined by the Kjeldahl method (AOAC, 1974) using 6.38 as the conversion factor. The total fat content of the washed cream was determined using the Röse-Gottlieb method (IDF, 1987). The DM content was gravimetrically determined after oven drying to constant weight at $105^{\circ} \mathrm{C}$.

Polar lipids of the samples were extracted and analyzed using the HPLC method developed by Rombaut et al. (2005) with some modifications. A Shimadzu HPLC system (Tokyo, Japan) was used in combination with an evaporative light-scattering detector (Alltech-3300, Alltech Associates Inc., Lokeren, Belgium). The evaporative light-scattering detector conditions were $1.6 \mathrm{~L} /$ min for the gas flow rate, $65^{\circ} \mathrm{C}$ for nebulizing temperature, and 1 for the acquisition gain. The mobile phase was pumped with a linear gradient program of 3 efflu- 


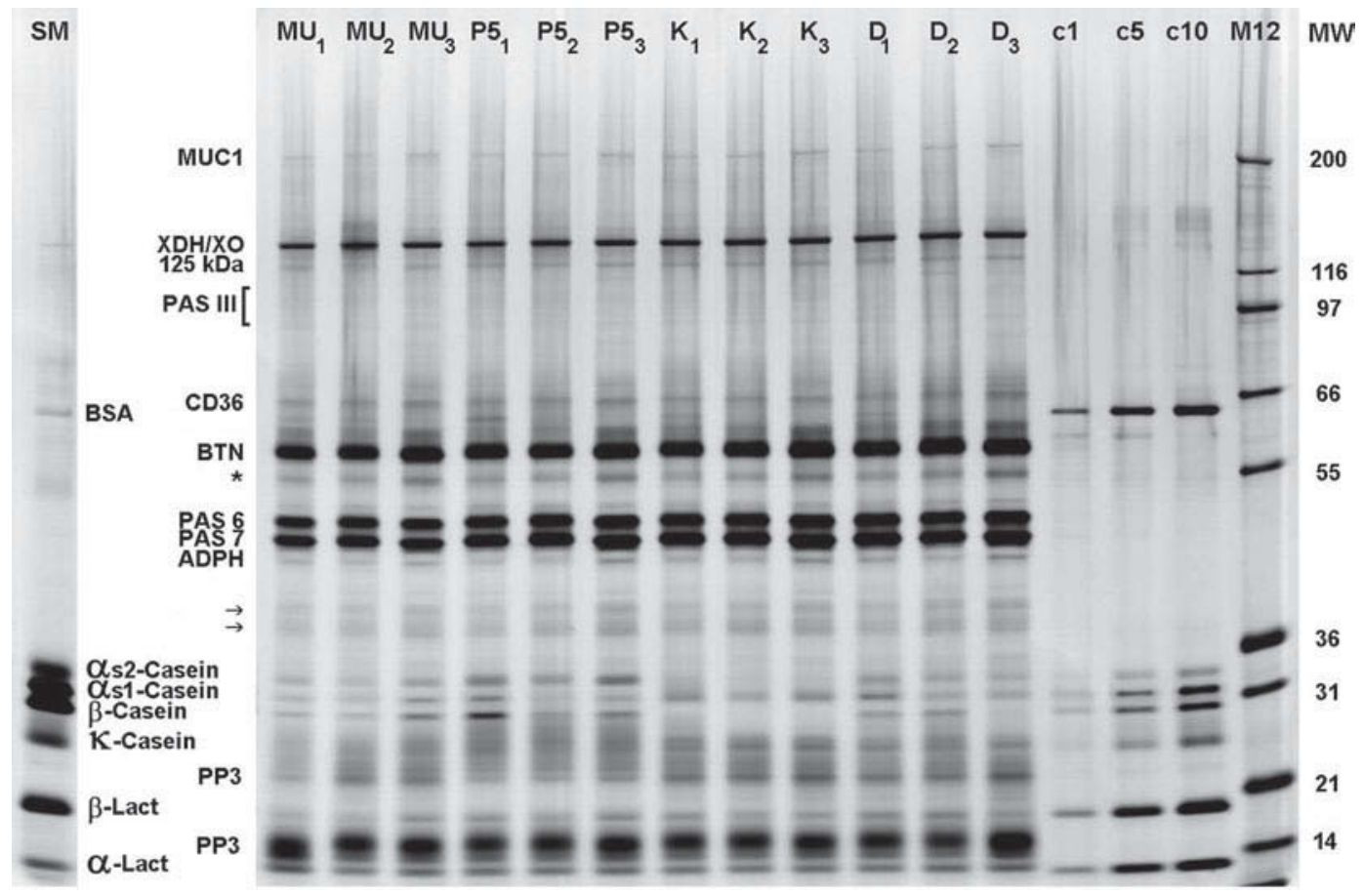

Figure 2. Sodium dodecyl sulfate-PAGE pattern of milk fat globule membrane (MFGM) samples obtained from different washing solutions: $\mathrm{MU}=$ milk ultrafiltrate; $\mathrm{P} 5=50 \mathrm{~m} M$ phosphate, $\mathrm{pH} 6.8$, and $0.15 \mathrm{M} \mathrm{NaCl} ; \mathrm{K}=1.5 \mathrm{~g}$ of $\mathrm{KCl} / \mathrm{L}$ of water; $\mathrm{D}=$ deionized water. The sample load on each lane was $100 \mathrm{ng}$ of total protein. Subscripts 1, 2, and 3 indicate replicates 1, 2, and 3, respectively. Other lanes: SM = $100 \mathrm{ng}$ of skimmed milk proteins; $\mathrm{c} 1, \mathrm{c} 5$, and $\mathrm{c} 10=$ pure proteins $\left(\mathrm{BSA}, \alpha_{\mathrm{S}^{-}} \mathrm{CN}, \beta-\mathrm{CN}, \kappa-\mathrm{CN}, \beta-\mathrm{LG}\right.$, and $\alpha-\mathrm{LA}$ ) loaded at 1,5 , and $10 \mathrm{ng}$ of each protein, respectively; and M12 = molecular weight indicator. Identification of MFGM proteins according to Mather (2000) and other proteins is given on the left; MUC1 = mucin 1; XDH/XO = xanthine dehydrogenase/oxidase; PAS III = periodic acid Schiff III; CD36 = cluster of differentiation $36, \mathrm{BTN}=$ butyrophilin; PAS $6 / 7=$ periodic acid Schiff $6 / 7 ; \mathrm{ADPH}=$ adipophilin; PP3 $=$ proteose peptone 3 . The asterisk $(*)$ indicates variants of the fragment of BTN released by proteolysis and lacking the C-terminus (Mather, 2000). One of the bands at the arrows could be apolipoprotein E (Fong et al., 2007).

ents: chloroform, methanol, and triethylamine buffer. The elution changed from 87.5:12:0.5 (vol:vol:vol) at $t$ $=0$ min to 2.0:90:8.0 (vol:vol:vol) after 12 min. This condition was maintained until $t=18 \mathrm{~min}$, and the mobile phase was brought back to initial conditions at $t=20 \mathrm{~min}$. The column was regenerated under initial conditions for $10 \mathrm{~min}$ before the next injection. For each sample, the extraction was carried out in duplicate and each replicate was injected twice on the HPLC.

\section{Electrophoresis}

The separation system and all reagents were obtained from Invitrogen (Merelbeke, Belgium). Sample preparation and reduction was performed following the manufacturer's protocol. Two hundred fifty microliters of NuPAGE LDS sample buffer and $100 \mu \mathrm{L}$ of NuPAGE reducing agent were added to $650 \mu \mathrm{L}$ of sample. The samples were vortexed and heated at $70^{\circ} \mathrm{C}$ for $10 \mathrm{~min}$ in a temperature-controlled water bath.

Five microliters of samples was added to each well of a precast NuPAGE bis-tris $4-12 \%$ polyacrylamide gel. The same amount of 20 time-diluted Mark12, the molecular weight (MW) standard solution, was also loaded on the gel. The gel cassette was placed in the Xcell Surelock system, which was connected to the Powerease 500 power unit. NuPAGE MOPS-buffer (3-N-morpholinopropane-sulfonic acid) was used as the running buffer. Separation was performed in 55 min at $200 \mathrm{~V}$ and an initial current of $125 \mathrm{~mA}$ per gel.

Visualization of the gels was performed with SilverXpress silver staining following the manufacturer's protocol (Invitrogen). Wet stained gels were scanned at 400 dpi using a high-resolution transmission scanner (UMAX Powerlook III, Taipei, Taiwan) and analyzed by densitometry with Imagemaster totallab software (GE Healthcare, Diegem, Belgium). The MFGM proteins were identified by comparing their MW with the MW standard, and named according to Mather (2000).

To determine the amount of contaminating proteins in the MFGM-protein samples, known amounts of purified BSA, $\alpha_{S^{-}} \mathrm{CN}, \beta-\mathrm{CN}, \kappa-\mathrm{CN}, \beta-\mathrm{LG}$, and $\alpha-\mathrm{LA}$ were loaded onto each gel. First, a test was carried out to determine at which concentration range a linear cali- 
bration curve was found for the content versus band intensity of contaminant proteins loaded onto the gel. When standards of contaminant proteins were loaded simultaneously onto the gels (e.g., lanes c1, c5, and c10 in Figure 2), the upper limits of loading that gave a linear calibration curve were about 12 to $14 \mathrm{ng}$ of each protein. The lower limits were $0.5 \mathrm{ng}$ for $\beta-\mathrm{CN}$ and $\kappa-\mathrm{CN}$ and $0.25 \mathrm{ng}$ for the other proteins. The $\mathrm{R}^{2}$ values of the calibration curves using 9 to 10 loading points in their linear ranges were $\geq 0.97$. To avoid errors due to extrapolation, the content of a contaminant protein in the sample was ignored if it was less than the lower limit of that protein, and the standard proteins were loaded onto each sample gel for quantitative determination to avoid variation between gels. Three to 8 standard points in the linear range were loaded on one gel depending on the availability of the gel lanes. The samples and the standard proteins were prepared in the same way; for example, reducing at $70^{\circ} \mathrm{C}$ before loading on the gel so that denaturation of the proteins was not expected to influence the quantitative determination.

Using the linear calibration curves of content versus band intensity for each contaminating protein, the amount of these proteins in the sample was determined and expressed as a percentage of the total amount of proteins in the sample. The percentage of contaminating proteins to total proteins was assumed to be maintained from the washed cream to the MFGM suspension. The MFGM protein content of the washed cream could thus be obtained by subtracting the total protein content as determined by the Kjeldahl method from the content of contaminant proteins as determined by SDS-PAGE. The equation for the calculation was as follows: MFGM proteins of washed cream $=$ total proteins of the washed cream - (total proteins of the washed cream $) \times(\%$ of non-MFGM proteins of the washed cream), where percentage of non-MFGM proteins of the washed cream was assumed to be the percentage of non-MFGM proteins of the MFGM suspension. The content of MFGM proteins calculated per amount of fat $(\mathrm{mg} / \mathrm{g})$ in the washed cream was used as a parameter to determine and compare the yield of MFGM proteins isolated from different experimental runs. This parameter was used instead of the amount of MFGM proteins calculated per initial amount of milk to avoid errors caused by losses of material during isolation (e.g., sticking of milk and cream to the centrifuge and containers).

\section{Determination of Average Fat Globule Size}

Size distribution of fat globules was determined with a long bench Malvern Mastersizer S (Malvern Instruments, Malvern, UK) using an MS17 automated sample dispersion unit as sampling unit, and code 3_PM01
$(1.492,0.01$ in 1.33$)$ as the presentation method. One percent of the milk or cream samples was dispersed in water or in SDS/EDTA solution (Ye et al., 2004a) before the measurement; SDS was used to disperse floccules of the fat globules and EDTA was used to dissociate the casein micelles. Sauter mean diameters, $\mathrm{d}_{(3,2)}$ $=\Sigma n_{i} d_{i}^{3} / \Sigma n_{i} d_{i}^{2}$, where $n_{i}$ is the number of fat globules with diameter $d_{i}$, were used to compare the result. The measurement on each sample was done at least twice and average values were taken.

\section{Experimental Treatments}

Influence of Washing Solutions. The effect of type of washing solution on the loss of MFGM proteins was evaluated. Four aqueous washing solutions were chosen to wash the cream: 1) milk ultrafiltrate (MU) or simulated milk ultrafiltrate, SMUF; Jenness and Koops, 1962); 2) $50 \mathrm{mM}$ phosphate, $\mathrm{pH} 6.8$, and 0.15 $M \mathrm{NaCl}$ (P5; Nielsen and Bjerrum, 1977); 3) $1.5 \mathrm{~g}$ of $\mathrm{KCl} / \mathrm{L}$ of water $(\mathbf{K})$; and 4 ) deionized water $(\mathbf{D})$. Cream was separated from $5 \mathrm{~L}$ of milk and washed 3 times with $4.5 \mathrm{~L}$ of the washing solution (about 9 volumes of the cream to reconstitute approximately the initial $5 \mathrm{~L}$ ) at $42^{\circ} \mathrm{C}$. The experiment was carried out in triplicate with each replicate performed on a different day.

Influence of Washing Temperature. The washing solution with the highest yield of MFGM proteins in the first experiment was used to wash the cream. Three different temperatures for fat globule separation and cream washing, 38,42 , and $46^{\circ} \mathrm{C}$, were investigated. The experiment was carried out in 4 replicates on different days whereby other conditions were the same as those in the previous experiment.

Influence of Number of Washes and Volume of Washing Solution. The type of washing solution and the temperature chosen from the experiments above were used as fixed factors in this part of the study. The experiment was constructed as a $2^{2}$ design to consider simultaneously the effect of 2 factors - number of washes and volume of washing solution - on the loss of MFGM proteins. Four corner points were 4 combinations of number of washes (2 and 3) and total volume of washing solution $(6.75$ and $13.5 \mathrm{~L})$; A (2 washes, $6.75 \mathrm{~L}), \mathrm{B}(3$ washes, $6.75 \mathrm{~L}), \mathrm{C}(3$ washes, $13.5 \mathrm{~L})$, and D (2 washes, $13.5 \mathrm{~L})$. In addition, E, a run of 2 washes of $\mathrm{C}$ in which $4.5 \mathrm{~L}$ of washing solution for each wash was used, was also considered. The experiment was repeated 4 times on different days.

\section{Statistical Analysis}

One- and 2-way ANOVA tests were performed using S-Plus 6.1 package for Windows (S-Plus, Tibco 


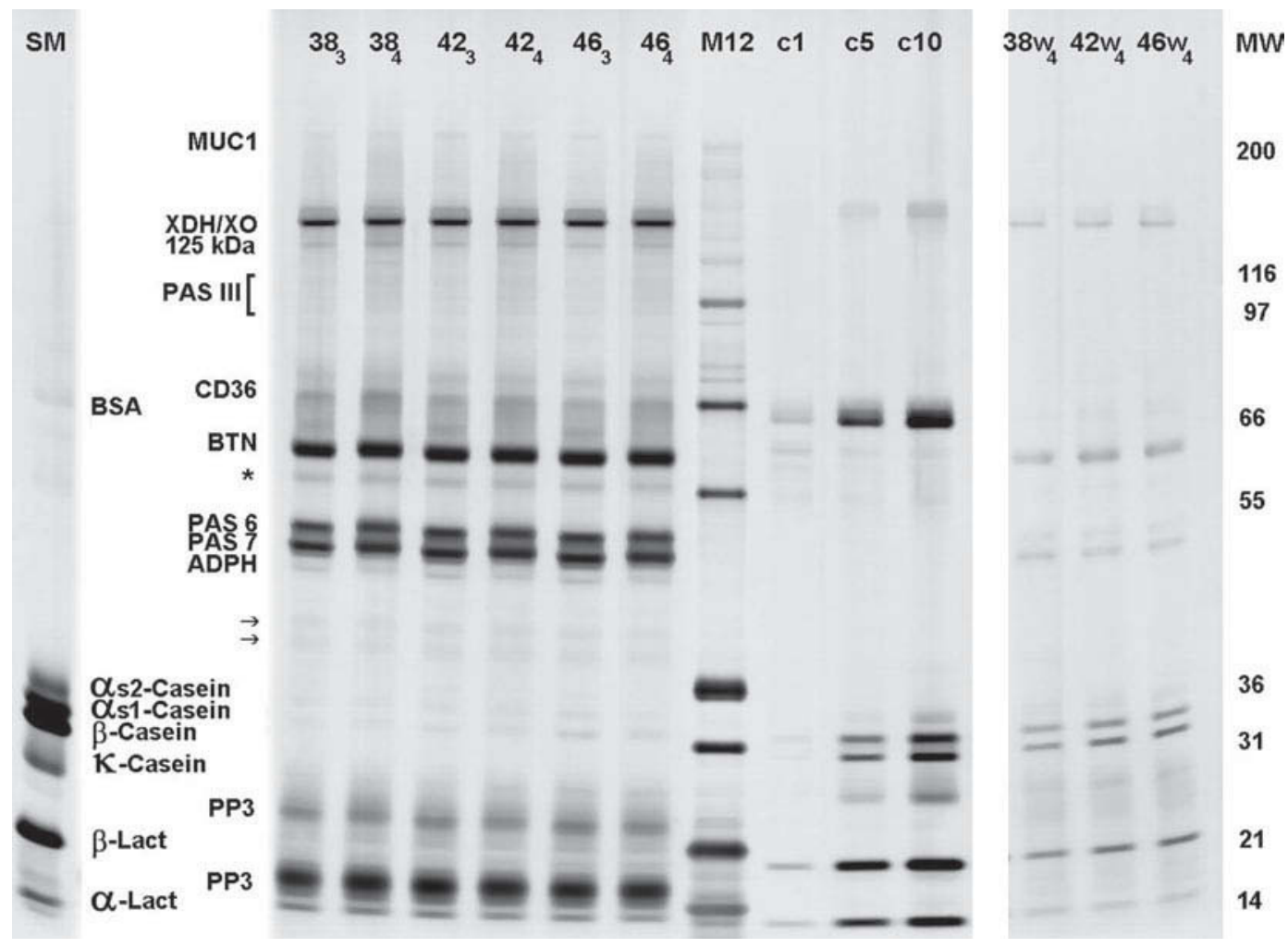

Figure 3. Sodium dodecyl sulfate-PAGE pattern of milk fat globule membrane (MFGM) samples obtained from different washing temperatures: 38,42 , and $46^{\circ} \mathrm{C}$. The sample load of total protein on each lane was $100 \mathrm{ng}$. Subscripts 3 and 4 indicate replicates. Other lanes: SM $=100$ ng of skim milk proteins; $\mathrm{c} 1, \mathrm{c} 5$, and $\mathrm{c} 10=$ pure proteins $\left(\mathrm{BSA}, \alpha_{\mathrm{S}} \mathrm{CN}, \beta-\mathrm{CN}, \kappa-\mathrm{CN}, \beta-\mathrm{LG}\right.$, and $\left.\alpha-\mathrm{LA}\right)$ loaded at 1,5 , and $10 \mathrm{ng}$ of each protein, respectively; and M12 = molecular weight indicator. Lanes $38 \mathrm{w}, 42 \mathrm{w}$, and $46 \mathrm{w}$ were loaded with $0.5 \mu \mathrm{L}$ of the third discharged washing solutions of isolation at 38,42 , and $46^{\circ} \mathrm{C}$. The lanes contained 30, 36, and $41 \mathrm{ng}$ of total proteins, respectively. Identification of MFGM proteins according to Mather (2000) and other proteins is given on the left; MUC1 = mucin 1; XDH/XO = xanthine dehydrogenase/oxidase; PAS III = periodic acid Schiff III; CD36 = cluster of differentiation 36, BTN = butyrophilin; PAS $6 / 7=$ periodic acid Schiff $6 / 7$; ADPH = adipophilin; PP3 = proteose peptone 3. The asterisk $(*)$ indicates variants of the fragment of BTN released by proteolysis and lacking the C-terminus (Mather, 2000). One of the bands at the arrows could be apolipoprotein E (Fong et al., 2007).

Software, Palo Alto, CA). Paired comparisons between means were carried out using the Tukey's test when a significant difference $(P<0.05)$ was observed.

\section{RESULTS}

\section{Electrophoresis}

Figures 2 and 3 show the SDS-PAGE patterns of MFGM samples obtained from different washing solutions and temperatures. Protein bands were well separated. Mucin 1 was resolved in one sharp and faint band at MW >200 kDa; PAS 6 and PAS 7 separated well. Figure 2 shows that adipophilin (ADPH) separated well from PAS 6 and PAS 7. The bands resolved at proteose peptone 3 (PP3) positions were very pronounced. The absolute intensity of bands occurring at PP3 positions on the SDS-PAGE was found to increase with increasing washing temperatures and when the number of washes increased from 2 to 3 (next experiments). Fatty acid binding protein (FABP) was not resolved in the SDS-PAGE pattern of our samples. It is one of the major proteins in MFGM with an apparent molecular weight of $13 \mathrm{kDa}$ and can be stained with both Coomassie Blue and silver. In addition to the major bands, many minor bands were visualized in the gels. It should be noted that for one-dimensional electrophoresis, one band can cover more than one protein or several variants of one protein.

\section{Influence of the Washing Solutions}

Samples of MFGM suspensions obtained from using the 4 washing solutions (MU, P5, K, and D) were electrophoretically mobilized on the gel, and the separated bands were visualized using silver staining. The stained gel of the 3 replicates with a sample load of $100 \mathrm{ng}$ of total protein per lane is presented in Figure 2. To calculate the content of non-MFGM proteins (BSA, $\alpha_{S^{-}}$ $\mathrm{CN}, \beta-\mathrm{CN}, \kappa-\mathrm{CN}, \beta-\mathrm{LG}$, and $\alpha-\mathrm{LA})$ in the samples, the 
Table 1. Yield of milk fat globule membrane (MFGM) proteins and percentage of contaminant proteins in the MFGM samples obtained from different washing solutions ${ }^{1}$

\begin{tabular}{lccc}
\hline Washing solution $^{2}$ & $\begin{array}{c}\text { Total protein } \\
(\mathrm{mg} / \mathrm{g} \text { of fat })\end{array}$ & $\begin{array}{c}\text { Cont. protein } \\
\text { (\% of total protein })\end{array}$ & $\begin{array}{c}\text { MFGM protein } \\
\text { (mg/g of fat) }\end{array}$ \\
\hline MU & $4.65 \pm 0.47$ & $12.57 \pm 1.81$ & $4.07 \pm 0.42$ \\
P5 & $5.01 \pm 0.31$ & $19.06 \pm 4.26$ & $4.04 \pm 0.04$ \\
K & $4.75 \pm 0.08$ & $12.04 \pm 1.42$ & $4.18 \pm 0.05$ \\
D & $5.11 \pm 0.77$ & $11.54 \pm 2.24$ & $4.53 \pm 0.74$ \\
\hline
\end{tabular}

${ }^{1}$ Data are means \pm sample SD. No significant difference was found within columns.

${ }^{2} \mathrm{MU}=$ milk ultrafiltrate; $\mathrm{P} 5=50 \mathrm{~m} M$ phosphate, $\mathrm{pH} 6.8$, and $0.15 \mathrm{M} \mathrm{NaCl} ; \mathrm{K}=1.5 \mathrm{~g}$ of $\mathrm{KCl} / \mathrm{L}$ of water; $\mathrm{D}$

$=$ deionized water.

${ }^{3}$ Cont. proteins $=$ contaminant proteins or non-MFGM proteins.

purified proteins were included in the same gel. Using the calibration curves constructed from 8 points loaded on the same gels (data not shown), their content as a percentage of total protein content was determined. The total protein content per unit of fat, the percentage of contaminant protein in the total protein fraction, and the MFGM protein content per unit of fat of the corresponding washed creams are tabulated in Table 1.

For all samples, residues of $\beta$-LG were $<1 \mathrm{ng} / 100 \mathrm{ng}$ of total proteins. The $\mathrm{K}$ and $\mathrm{P} 5$ wash solutions gave a significantly higher amount of $\kappa-\mathrm{CN}$ than MU and D (at a $5 \%$ level of significance). The P5 solution resulted in an MFGM preparation with the highest average content of contaminating proteins and lowest average yield of MFGM proteins. Differences in yield for the MFGM proteins recovered from different solutions were not statistically significant. However, based on average values, the yield of MFGM proteins decreased in the order $\mathrm{D}>\mathrm{K}>\mathrm{MU}>\mathrm{P} 5$. Presumably, deionized water could be considered the best washing solution, taking into account both the yield of MFGM proteins and the presence of contaminating proteins.

\section{Influence of the Washing Temperature}

Deionized water was used as the washing solution in this experiment. The separated cream was washed 3 times. Samples of MFGM suspensions from the 3 dif- ferent washing temperatures were loaded at $100 \mathrm{ng}$ of total protein on the SDS-PAGE gel (Figure 3). There was no significant difference for washing temperature on the degree of contamination. $\kappa$-Casein and $\alpha$-LA were found to contribute most to this contamination for all samples. A decrease in average recovery of MFGM proteins was seen when the washing temperature increased from 38 to $46^{\circ} \mathrm{C}$ in all 4 experimental replicates; however, this was not statistically significant (Table 2 ). Several major MFGM proteins such as XO, butyrophilin, and PAS 6/7 were clearly seen on the lanes of discharged washing solutions after 3 washes (Figure 3 ).

\section{Influence of Number of Washes and Volume of Washing Solution}

When washing was performed at $38^{\circ} \mathrm{C}$, small butter granules appeared in the cream after the second wash. To avoid an uncontrollable effect of coalescence, $42^{\circ} \mathrm{C}$ was chosen as the temperature for fat separation and cream washing in this experiment. The results are shown in Table 3. The calibration curves of the standard proteins in this experiment were constructed from 4 points loaded onto the same gel with the samples.

The contamination level of A samples was found to be significantly higher than that of $\mathrm{C}$ samples (at the $5 \%$ level of significance). When the result was arranged to test the effect of volume of the washing solution and number of washes (E not included), 2-way ANOVA

Table 2. Yield of milk fat globule membrane (MFGM) proteins and percentage of contaminant proteins in the MFGM samples obtained from different washing temperatures ${ }^{1}$

\begin{tabular}{lccc}
\hline Washing temperature $\left({ }^{\circ} \mathrm{C}\right)$ & $\begin{array}{l}\text { Total protein } \\
(\mathrm{mg} / \mathrm{g} \text { of fat })\end{array}$ & $\begin{array}{c}\text { Cont. protein }{ }^{2} \\
(\% \text { of total protein })\end{array}$ & $\begin{array}{c}\text { MFGM protein } \\
(\mathrm{mg} / \mathrm{g} \text { of fat })\end{array}$ \\
\hline 38 & $5.35 \pm 0.11^{\mathrm{a}}$ & $7.68 \pm 1.44^{\mathrm{a}}$ & $4.93 \pm 0.09^{\mathrm{a}}$ \\
42 & $4.99 \pm 0.17^{\mathrm{b}}$ & $7.70 \pm 2.08^{\mathrm{a}}$ & $4.61 \pm 0.24^{\mathrm{a}}$ \\
46 & $4.86 \pm 0.29^{\mathrm{b}}$ & $7.41 \pm 1.61^{\mathrm{a}}$ & $4.50 \pm 0.34^{\mathrm{a}}$ \\
\hline${ }^{\mathrm{a}, \mathrm{b}}$ Values within a column without a common superscript differ $(P<0.05)$. & \\
${ }^{1}$ Data are means \pm sample SD. &
\end{tabular}



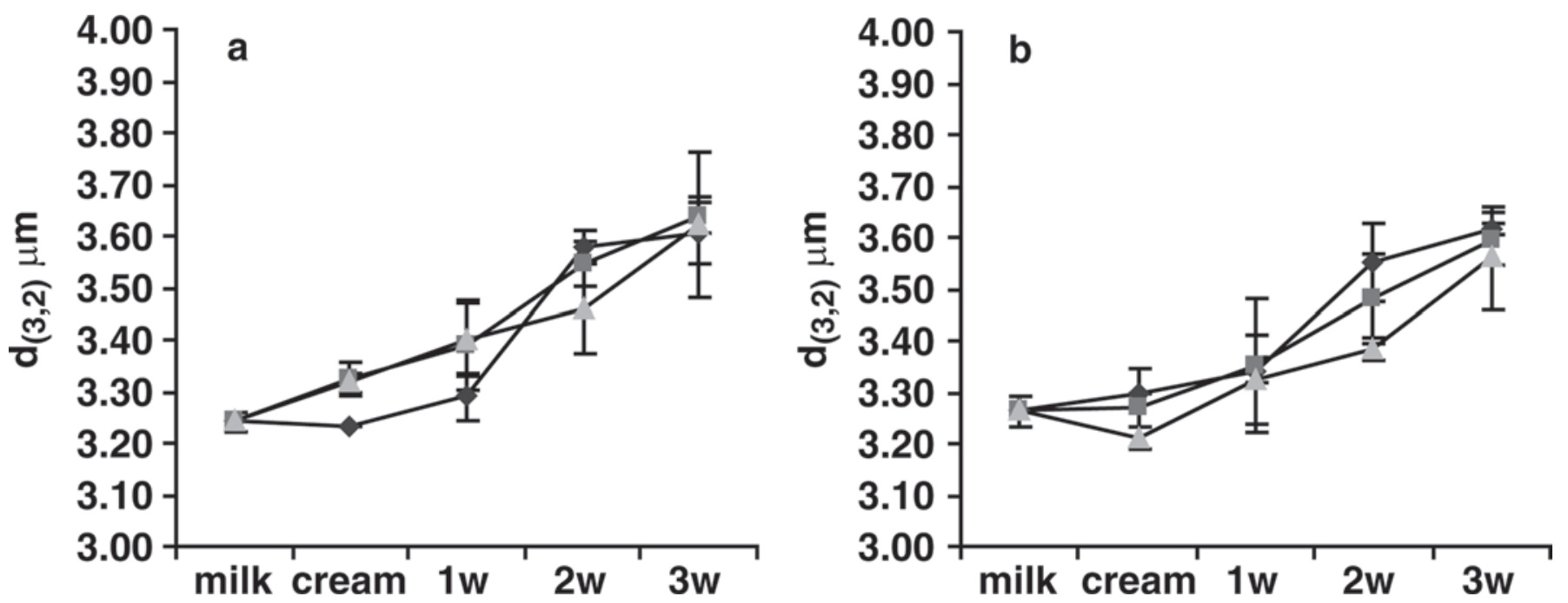

Figure 4. Sauter mean diameter $\left[\mathrm{d}_{(3,2)}\right]$ of fat globules of milk, separated cream (cream), and that after the first $(1 \mathrm{w})$, second $(2 \mathrm{w})$, and third $(3 \mathrm{w})$ wash at $38(--), 42(--)$ and $46^{\circ} \mathrm{C}(-\boldsymbol{-}-)$. The samples were dispersed in a) water and b) SDS/EDTA solution before measuring.

indicated that, compared with the 2-wash procedure, 3 washings resulted in MFGM samples with significantly lower contamination $(P=0.03)$. Lower contamination was also observed when $13.5 \mathrm{~L}$ of washing solution was used compared with $6.75 \mathrm{~L}(P=0.006)$. Because of large variation among the experimental replicates, no $P$-values were found to be $\leq 0.05$ when evaluating the effect of the 2 parameters on the yield of MFGM proteins. However, as expected, the number of washes more strongly affected the yield of MFGM proteins than did the volume of the washing solution $(P$-value $=0.06$ vs. 0.78 ).

A recovery of $4.61 \pm 0.29 \mathrm{mg}$ of total proteins/g of fat was obtained with the $\mathrm{C}$ procedure. Although the cream was washed 3 times with a total of $13.5 \mathrm{~L}$ of deionized water, the non-MFGM proteins in the $\mathrm{C}$ sample still comprised $7.86 \pm 1.34 \%$ of the total pro- teins (Table 3). To this non-MFGM part, $\alpha_{S^{-}} \mathrm{CN}, \beta-\mathrm{CN}$, $\kappa-\mathrm{CN}, \beta-\mathrm{LG}$, and $\alpha$-LA contributed $0.75 \pm 0.24,0.43$ $\pm 0.08,4.03 \pm 0.79,0.74 \pm 0.14$, and $1.91 \pm 1.05 \%$, respectively. The intensity of both bands corresponding to PP3 was observed to increase when the number of washes increased from 2 (D samples) to 3 (C samples) (data not shown). This was also seen when the washing temperature increased from 38 to $46^{\circ} \mathrm{C}$ in the previous experiment.

\section{Milk Fat Globule Size}

Milk and cream samples taken during isolation from the last 2 replicates of the experiment with washing temperature were analyzed on fat globule size distribution. Average fat globule diameters of these samples are shown in Figure 4.

Table 3. Yield of milk fat globule membrane (MFGM) proteins and percentage of contaminant proteins in the MFGM samples obtained from different washing procedures ${ }^{1}$

\begin{tabular}{lccc}
\hline Sample $^{2}$ & $\begin{array}{c}\text { Total protein } \\
(\mathrm{mg} / \mathrm{g} \text { of fat })\end{array}$ & $\begin{array}{c}\text { Cont. protein } \\
\text { (\% of total protein })\end{array}$ & $\begin{array}{c}\text { MFGM protein } \\
\text { (mg/g of fat) }\end{array}$ \\
\hline A $(2 \mathrm{~W}, 6.75 \mathrm{~L})$ & $5.32 \pm 0.25^{\mathrm{a}}$ & $15.95 \pm 4.66^{\mathrm{a}}$ & $4.47 \pm 0.27^{\mathrm{a}}$ \\
$\mathrm{D}(2 \mathrm{~W}, 13.5 \mathrm{~L})$ & $5.04 \pm 0.16^{\mathrm{ab}}$ & $10.84 \pm 2.98^{\mathrm{ab}}$ & $4.49 \pm 0.07^{\mathrm{a}}$ \\
B $(3 \mathrm{~W}, 6.75 \mathrm{~L})$ & $4.77 \pm 0.31^{\mathrm{bc}}$ & $12.04 \pm 1.56^{\mathrm{ac}}$ & $4.19 \pm 0.32^{\mathrm{a}}$ \\
C $(3 \mathrm{~W}, 13.5 \mathrm{~L})$ & $4.61 \pm 0.29^{\mathrm{c}}$ & $7.86 \pm 1.34^{\mathrm{b}}$ & $4.25 \pm 0.31^{\mathrm{a}}$ \\
E $(2 \mathrm{~W}, 9 \mathrm{~L})$ & $5.30 \pm 0.29^{\mathrm{a}}$ & $12.14 \pm 2.11^{\mathrm{ab}}$ & $4.65 \pm 0.20^{\mathrm{a}}$ \\
\hline
\end{tabular}

${ }^{\text {a c }}$ Values within a column without a common superscript differ $(P<0.05)$.

${ }^{1}$ Data are means \pm sample SD. Different combinations of 2 parameters (number of washes and volume of the washing solution) were used.

${ }^{2} 2 \mathrm{~W}$ and $3 \mathrm{~W}$ indicate 2 or 3 washes; volume shown is the total volume of washing solution used to isolate that sample. The volume of initial milk for each run was $5 \mathrm{~L}$.

${ }^{3}$ Cont. protein $=$ contaminant proteins or non-MFGM proteins. 

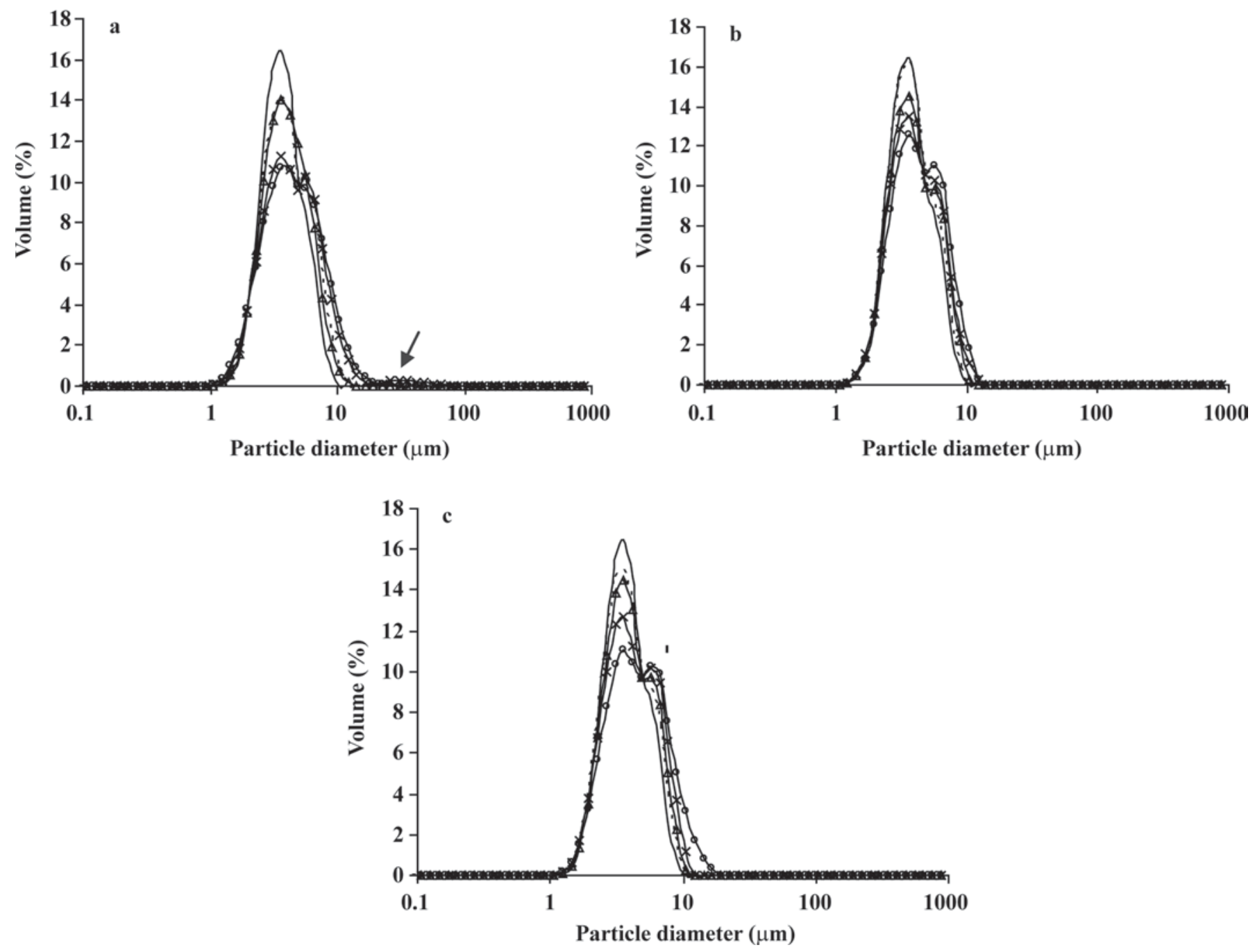

Figure 5. Fat globule size distributions in volume percentage versus droplet diameter of milk (-) and separated cream (----) and cream after the first $(-\Delta-)$, the second $(-\times-)$, and the third wash $(-\mathrm{O}-)$, which were determined after dispersing the samples in water. Cream separation and washing was done at a) 38 , b) 42 , and c) $46^{\circ} \mathrm{C}$. The arrow points to a small and broad peak between 10 and $100 \mu \mathrm{m}$.

The average diameters of the fat globules increased throughout the isolation process. The results obtained from measuring in water or in SDS solution showed similar trends. Generally at all 3 temperatures, $\mathrm{d}_{(3,2)}$ of the fat globules increased significantly after the second wash of the creams (Figure 4). This is illustrated in the size distribution graphs (Figure 5), where the curves of washed creams widened to the right to $>10 \mu \mathrm{m}$ compared with that of milk. The "shoulder" (indicated by ' on panel c) increased and became a visibly separate peak when isolation proceeded from milk to separated cream and creams after 1,2 , and 3 washes. These findings may indicate that coalescence of fat globules occurred during isolation of MFGM. A broad but low peak was observed (indicated by the arrow) between 10 and $100 \mu \mathrm{m}$ in the cream sample of $38^{\circ} \mathrm{C}$ after the second wash but disappeared after the third wash.

\section{Gross Composition}

From the third experiment, procedure E was a better washing procedure compared with procedure $\mathrm{C}$ when taking into account the time and water consumption. The lyophilized MFGM material obtained from isolation with procedure E comprised $24.96 \pm 0.50 \%$ proteins, $72.98 \pm 1.25 \%$ lipid, and $4.26 \pm 1.53 \%$ water. Of the protein fraction, about $12.14 \%$ belonged to non-MFGM proteins in which the contribution of $\alpha-\mathrm{CN}, \beta-\mathrm{CN}, \kappa-\mathrm{CN}$, $\beta$-LG, and $\alpha$-LA were $2.00 \pm 1.61,0.39 \pm 0.03,6.49 \pm$ $1.38,0.89 \pm 0.19$, and $2.37 \pm 1.22 \%$, respectively. Of the lipid fraction, polar lipids comprised $30.63 \pm 4.52 \%$ with their composition (phosphatidyl ethanolamine: phosphatidyl inositol: phosphatidyl serine: phosphatidyl choline : sphingomyelin) being $32.94 \pm 0.44$ : 7.08 \pm 0.06: $5.02 \pm 0.43: 29.16 \pm 0.17: 25.8 \pm 0.98$. Two 


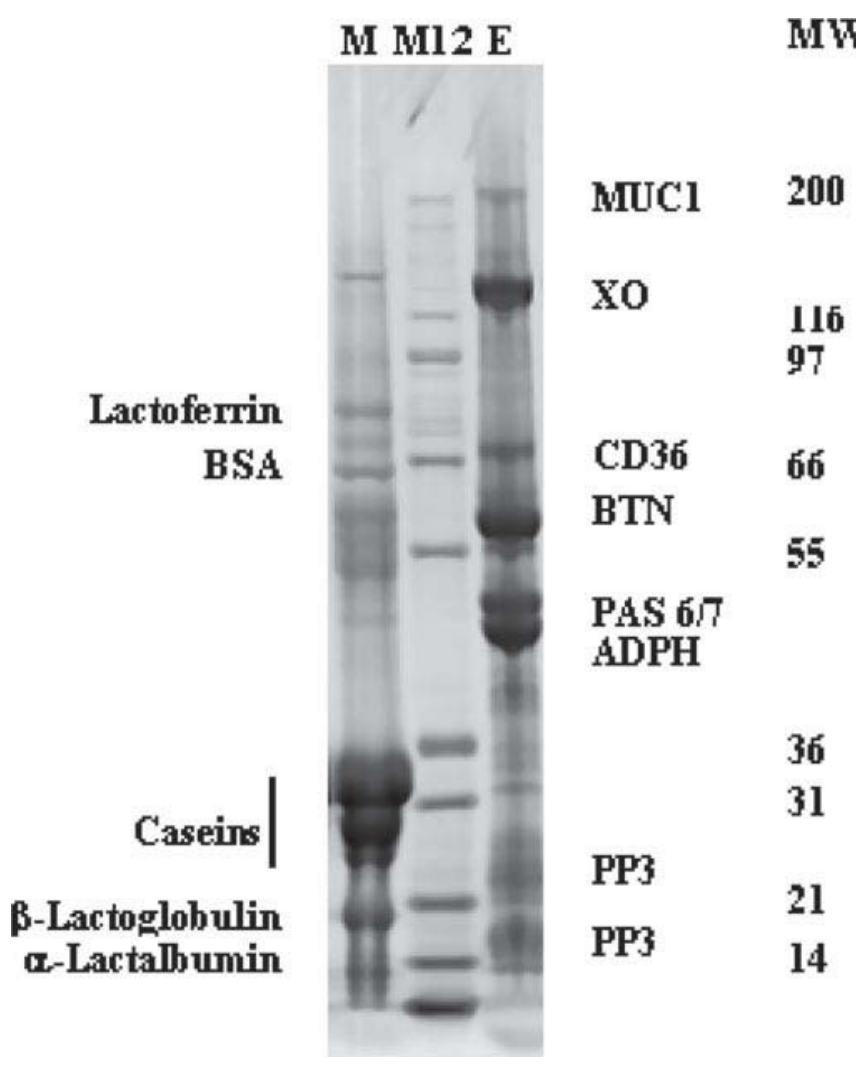

Figure 6. Sodium dodecyl sulfate-PAGE pattern of milk (M) and milk fat globule membrane (MFGM) sample (E) isolated using procedure $\mathrm{E}$ (2 washes with $4.5 \mathrm{~L}$ of deionized water) under the staining with Simply Blue (Invitrogen, Merelbeke, Belgium). The sample load on each lane was $20 \mu \mathrm{g}$ of total protein. M12 = molecular weight indicator. Identification of MFGM proteins according to Mather (2000) and other proteins is given on the right; $\mathrm{MUC1}=\operatorname{mucin} 1$; $\mathrm{XO}=$ xanthine oxidase; CD36 = cluster of differentiation 36 , BTN = butyrophilin; PAS $6 / 7=$ periodic acid Schiff $6 / 7 ; \mathrm{ADPH}=$ adipophilin; $\mathrm{PP} 3=$ proteose peptone 3 .

other isolation batches using procedure $\mathrm{E}$ with the buttermilk and butter serum collected separately showed that among the total proteins, $52 \%$ were recovered in the buttermilk and $48 \%$ were recovered in the butter serum. Recovery of $5.30 \pm 0.29 \mathrm{mg}$ of total proteins $/ \mathrm{g}$ of fat was obtained in the cream washed using the $\mathrm{C}$ procedure (Table 3 ). The original milk contained about $695 \mathrm{mg}$ of total proteins/g of fat. The SDS-PAGE pattern of milk showed mainly skim milk proteins, whereas proteins of the MFGM isolate contained mainly MFGM proteins (Figure 6).

\section{DISCUSSION}

Silver staining is about 50 to 100 times more sensitive than Coomassie Blue staining, thereby increasing resolution as separation of protein bands is increased. The small loads required made it possible to use MFGM suspension instead of MFGM powder. The amount of proteins in the former was too low to apply Coomassie Blue staining. Using Coomassie Blue may result in problems with rehydration of the sample (Fong et al., 2007), leading to inaccuracy upon quantitative analysis. With silver staining, the staining intensity varies between gels. The inclusion of standard proteins on the same gel was necessary to allow an accurate quantitative determination of their concentrations in the samples. All standard proteins mentioned could be loaded simultaneously on the same gel lane using a small load and giving good separation between the individual proteins.

The band appearing at $125 \mathrm{kDa}$ (Figure 3) corresponds to the band migrating at $135 \mathrm{kDa}$ in the work of Singh (2006), which migrated faster than that of XO. In our gradient gels, PAS 6, PAS 7, and ADPH separated quite well. In electrophoresis using single-concentration acrylamide gels, PAS 6 and PAS 7 often co-migrate into a broad or a double band in which ADPH is covered (Hvarregaard et al., 1996; Mather, 2000; Singh, 2006). However, band separation on SDS-PAGE depends not only on the type of gels but also on the load in each gel lane. The absence of FABP was likely because of the lower resolving capacity of the gel for this smaller molecular weight protein: FABP probably migrated to the bottom of the gel along with the electrophoresis dye front without being resolved. The MFGM has a complex protein composition with more than 40 proteins resolved using a combination of electrophoresis and isoelectric focusing (Singh, 2006). Because the purpose of the present research was not to identify all individual protein components, the reader is referred to the work of Ye et al. (2002), Fong et al. (2007), and the review of Mather (2000) for more information on minor proteins.

Of the 4 washing solutions compared in the second experiment, P5 contained the greatest amount of salts $(15.76 \mathrm{~g} / \mathrm{L})$ and gave the lowest yield of MFGM proteins on average. The review of Whitney (1999) shows that band intensity of casein components in the MFGM preparation differs with different washing solutions. Salts can dissociate casein micelles and the type of casein components attaching to the MFGM may depend on the type of salts used. The MU washing solution contained $6.75 \mathrm{~g} / \mathrm{L}$ of salts. This solution is often called SMUF and closely resembles the skim milk ultrafiltration permeate in $\mathrm{pH}$, conductivity, calcium ion activity, and titration curve (Jenness and Koops, 1962). In this study, SMUF was inferior to deionized water because the latter tends to reduce the loss of MFGM proteins. For fat separation and cream washing using small-scale laboratory centrifuges, where there is little mechanical impact, buffered salt solutions have been widely used and reported to be better than deionized water regard- 
ing purity of the MFGM preparation (e.g., Basch et al., 1985). Buttermilk (butter serum not included) obtained from cream washed with a sucrose-saline solution was reported to be richer in MFGM constituents compared with that obtained from cream washed with deionized water (Erickson et al., 1964). However, when washing is performed using a fat separator, salt solutions gave neither a higher yield of MFGM protein nor a lower contamination than deionized water.

Western blot analysis showed that PP3 was confirmed to be relatively strongly associated with the MFGM and to be present in the whey fraction but not in casein micelles (Sorensen et al., 1997). This pronounced appearance of PP3 has not been reported before, especially when the cream was washed and separated using laboratory centrifuges. The absolute intensity of bands occurring at PP3 positions increased with increasing washing temperatures and number of washes. This seems to show that these bands contained not only PP3 but also (probably) other polypeptides such as breakdown products of the MFGM or milk proteins. For example, several breakdown products of $\beta$-CN due to plasmin activity are identified in milk and they occur in the proteose peptone fraction (Whitney, 1999). If these hydrolysis products were from one of the determined non-MFGM proteins, the hydrolysis would partially contribute to the variation observed between experiment replicates. Some of the PP3 in the MFGM material can be the result of its interaction with denuded surface of fat globules, which can be formed during contact with air bubbles as mentioned in the next paragraph. With the electrophoretic conditions applied in this study, PP3 bands occupied a large percentage of total staining intensity of a lane although PP3 is not considered a major protein in the MFGM. The staining with Coomassie Blue also resulted in broad bands at the location of PP3 but with much lower resolution (Figure 6).

The coalescence of fat globules occurred at all experimental temperatures after 2 washes but was more pronounced at $38^{\circ} \mathrm{C}$. At this temperature, more core triglyceride fat was in the form of crystals, which, under mechanical impact, disrupt the membrane of fat globules leading to their aggregation. The minute butter granules floating on the surface would not be pumped into the detecting system of the Mastersizer during analysis of particle size. This may explain the disappearance of the wide but small-in-volume peak between 10 and $100 \mu \mathrm{m}$ of the sample at $38^{\circ} \mathrm{C}$ after 3 washes (Figure 5a). This issue could lead to underestimation of the coalescence. The coalescence of fat globules caused by the presence of air bubbles is a well-known phenomenon. Inclusion of air into the milk may occur; for example, during its feeding into the fat separator. When the spreading pressure is positive, the oil of the fat globules in contact with air bubbles will spread over the air-water interface and when the bubbles collapse, the fat globules coalesce (Walstra et al., 2006). Fat globule aggregation increases the loss of MFGM components because of the decrease of specific surface area of fat globules (Walstra, 1985). The relative increase in $\mathrm{d}_{(3,2)}$ would then be roughly equal to the relative loss of membrane material. However, the loss caused by greater coalescence at $38^{\circ} \mathrm{C}$ did not give a lower yield of MFGM as when the temperature was 42 or $46^{\circ} \mathrm{C}$. In the absence of fat crystals in the globules (i.e., at the higher temperatures), full coalescence of globules may occur. The surface area of a globule formed from 2 completely coalesced globules would be smaller than that of a globule formed from 2 partially coalesced globules. This could be one of the reasons why the average loss of MFGM material at 46 or $42^{\circ} \mathrm{C}$ was higher than that at $38^{\circ} \mathrm{C}$. Ye et al. (2002) reported that there was loss of MFGM proteins when washing the cream at $45^{\circ} \mathrm{C}$ compared with washing at $20^{\circ} \mathrm{C}$.

At a washing temperature of $38^{\circ} \mathrm{C}$, the salt solutions (MU, P5) caused more coalescence of fat globules, as seen by more butter granules appearing, compared with deionized water. This may explain why, on average, a higher amount of MFGM proteins was recovered with deionized water as the washing solution. To a certain extent, electrostatic repulsion between fat globules plays a role in preventing them from coalescing. The salts decrease the thickness of the electrical double layer such that the stability of the globules to aggregation is decreased.

There was a slight difference in the average yield of MFGM proteins from the same washing procedure from experiments 1 to 3 , namely $\mathrm{D}$, with $4.53 \pm 0.74,42^{\circ} \mathrm{C}$ with $4.61 \pm 0.24$, and $\mathrm{C}$ with $4.25 \pm 0.31$ ( $\mathrm{mg} / \mathrm{g}$ of fat). Changes in the size of fat globules during lactation leads to differences in the MFGM content (Ye et al., 2002). Not only the total yield, but also the composition of MFGM components changes during lactation (Mondy and Keenan, 1993; Ye et al., 2002) and is affected by the feed of cows (McPherson and Kitchen, 1983; Wiking et al., 2003).

Kanno and Kim (1990) obtained 3.59 g of MFGM fragments, in which proteins comprised $28.1 \%$, from $10 \mathrm{~kg}$ of milk. Assuming the milk contained $4 \%$ fat, their yield of the total proteins would be $2.53 \mathrm{mg} / \mathrm{g}$ of fat. Fong et al. (2007) obtained a similar result with that of Kanno and Kim (1990) and found that caseins made up to $5 \%$ of the total proteins. McPherson et al. (1984) recovered $8.5 \mathrm{mg}$ of MFGM material (including other components)/g of fat. However, Ye et al. (2002) reported a much higher yield, from 6.4 to $8.3 \mathrm{mg}$ of proteins/g of fat, depending on lactation period. The 
difference in treatment history of milk and applied washing procedures are some of the reasons causing the deviation in yield of MFGM proteins that have been reported by different authors. All reported values are much lower than the estimated composition of natural MFGM (Walstra et al., 2006). In our case, the release of MFGM proteins to the serum phase could have occurred during storage for several hours in the cooling tank at the farm (Evers, 2004) and during the isolation process because of the coalescence of fat globules and rearrangement of MFGM under, for example, elevated washing temperature and mechanical impact.

Content of polar lipids of the buttermilk and butter serum was not determined separately. However, it was reported that cream separated from raw milk comprised $48.4 \%$ polar lipids of the latter, and of this, about $60 \%$ were distributed to butter and $40 \%$ to buttermilk after a churning stage (Rombaut et al., 2006). A similar distribution of polar lipids was also reported in the work of Britten et al. (2008). More detail on polar lipid distribution between buttermilk and butter serum can be found in these 2 reports.

The greatest contribution to the non-MFGM protein contamination belonged to $\kappa-\mathrm{CN}$ and $\alpha-\mathrm{LA}$. During isolation, the disruption of MFGM at the contact zone between fat globules and air bubbles may produce affinity sites or exposed surface to which these caseins and whey proteins could adsorb. $\alpha$-Lactalbumin is partially buried in the bilayer membrane of mammary cells during the formation and secretion of milk, suggesting that there may be a certain affinity between $\alpha$-LA and the polar lipid bilayer membrane of the MFGM. Transmission electron microscopy of milk did not show any increase in concentration of caseins at the vicinity of the MFGM (Lee and Morr, 1992). This may exclude the hypothesis that these proteins interact readily with the MFGM in raw milk. Under heat treatment ( $>60$ to $65^{\circ} \mathrm{C}$ ) and homogenization, caseins, $\beta-\mathrm{LG}$, and $\alpha-\mathrm{LA}$ have been reported to interact with MFGM (Cano-Ruiz and Richter, 1997; Corredig and Dalgleish, 1997; Ye et al., 2004b). There was possibly a residue of other nonMFGM proteins in the obtained MFGM samples but their concentrations were smaller than the detection limit of the silver staining used in the present study. It is expected that their quantitative contribution is negligible. Washing cream with milk ultrafiltrate would increase the contamination of MFGM material with whey proteins because they may penetrate the ultrafiltration membrane (Britten et al., 2008). The microfiltration process for concentrating MFGM material from buttermilk is improved both in the hydrodynamic aspects of the process as well as the purity of phospholipids of the obtained material if the cream is washed with skim milk ultrafiltrate (Morin et al., 2007)
In the past decades, the MFGM as a whole or its components as well as its nutritional and technical (emulsifying) properties have been the subject of numerous studies (Singh, 2006). These unique properties make MFGM material a potential ingredient for the development of new functional foods. To investigate their application, a sufficient amount of MFGM sample is required. Materials enriched with MFGM isolated from buttermilk and butter serum are now commercially available. However, compared with the MFGM isolated from untreated milk, the materials isolated from these industrial sources, which have undergone several treatments, have different compositions and potentially different technical properties (Corredig and Dalgleish, 1997, 1998; Wong and Kitts, 2003; Roesch et al., 2004).

The results of the present study yield more information on how washing parameters influence the loss of MFGM proteins. Using deionized water as the washing solution did not increase the loss of MFGM proteins compared with common salt solutions in terms of recovery of MFGM proteins and contamination with nonMFGM proteins. Increasing the washing temperature from 38 to $46^{\circ} \mathrm{C}$ did not result in a significant decrease in yield of MFGM proteins because of variation between the experiment replicates. Coalescence of fat globules occurs during isolation. To increase MFGM purity while maintaining a high MFGM protein recovery, using larger volumes of washing solution is more advisable than increasing the number of washings from 2 to 3 . Washing the cream with deionized water avoids the need to remove salts from the MFGM material before its application. Enzyme activity in hydrolysis of fat or proteins was not investigated; this is a limitation of this study and warrants further investigation.

\section{ACKNOWLEDGMENTS}

The research was financially supported by the Laboratory of Food Technology and Engineering, Ghent University, by the BOF scholarship of Ghent University (BOF07/DOS/047). This work was also supported by the FWO (Fund for Scientific Research), Flanders, project number G.0490.08. Benny Lewille (Technician of the Laboratory of Food Technology and Engineering of Ghent University) is acknowledged for technical assistance.

\section{REFERENCES}

Anderson, M., and B. E. Brooker. 1974. Loss of material during the isolation of milk fat globule membrane. J. Dairy Sci. 58:14421448 .

AOAC. 1974. Official Methods of Analysis. 12th ed. Association of Analytical Chemists, Washington, DC. 
Basch, J. J., R. Greenberg, and H. M. Farrell Jr. 1985. Identification of the milk fat globule membrane proteins. II. Isolation of major proteins from electrophoretic gels and comparison of their amino acid compositions. Biochim. Biophys. Acta 830:127-135.

Britten, M., S. Lamothe, and G. Robitaille. 2008. Effect of cream treatment on phospholipids and protein recovery in butter-making process. Int. J. Food Sci. Technol. 43:651-657.

Cano-Ruiz, M. E., and R. L. Richter. 1997. Effect of homogenization pressure on the milk fat globule membrane proteins. J. Dairy Sci. 80:2732-2739.

Corredig, M., and D. G. Dalgleish. 1997. Isolates from industrial buttermilk: Emulsifying properties of materials derived from the milk fat globule membrane. J. Agric. Food Chem. 45:4595-4600.

Corredig, M., and D. G. Dalgleish. 1998. Effect of heating of cream on the properties of milk fat globule membrane isolates. J. Agric. Food Chem. 46:2533-2540.

Dewettinck, K., R. Rombaut, N. Thienpont, T. T. Le, K. Messens, and J. V. Camp. 2008. Nutritional and technological aspects of milk fat globule membrane material. Int. Dairy J. 18:436-457.

Erickson, D. R., W. L. Dunkley, and L. M. Smith. 1964. Tocopherol distribution in milk fractions and its relation to antioxidant activity. J. Food Sci. 29:269-275.

Evers, J. M. 2004. The milkfat globule membrane-compositional and structural changes post secretion by the mammary secretory cell. Int. Dairy J. 14:661-674.

Fong, B. Y., C. S. Norris, and A. K. H. MacGibbon. 2007. Protein and lipid composition of bovine milk-fat-globule membrane. Int. Dairy J. $17: 275-288$.

Hvarregaard, J., M. H. Andersen, L. Berglund, J. T. Rasmussen, and T. E. Petersen. 1996. Characterization of glycoprotein PAS-6/7 from membranes of bovine milk fat globules. Eur. J. Biochem. 240:628-636

IDF. 1987. Cream: Determination of fat content (Rose-Gottlieb). Standard 16:C. Int. Dairy Fed, Brussels, Belgium.

Jenness, R., and J. Koops. 1962. Preparation and properties of salt solution which simulates milk ultrafiltrate. Neth. Milk Dairy J. 16:153-167.

Kanno, C., and D.-H. Kim. 1990. A simple procedure for the preparation of bovine milk fat globule membrane and a comparison of its composition, enzymatic activities, and electrophoretic properties with those prepared by other methods. Agric. Biol. Chem. 54:2845-2854

Keenan, T. W., and I. H. Mather. 2006. Intracellular origin of milk fat globules and the nature of the milk fat globule membrane. Pages 137-171 in Advanced Dairy Chemistry. Vol. 2: Lipids. 3rd ed. P. F. Fox and P. L. H. McSweeney, ed. Springer, New York, NY.

Lee, S.-Y., and C. V. Morr. 1992. Fixation and staining milkfat globules in cream for transmission and scanning electron microscopy. J. Food Sci. 57:887-891.

Liu, C., A. K. Erickson, and D. R. Henning. 2005. Distribution and carbohydrate structures of high molecular weight glycoproteins, MUC1 and MUCX, in bovine milk. J. Dairy Sci. 88:4288-4294.

Mather, I. H. 2000. A review and proposed nomenclature for major proteins of the milk-fat globule membrane. J. Dairy Sci. 83:203247

Mather, I. H., K. Weber, and T. W. Keenan. 1977. Membranes of mammary gland. XII. Loosely associated proteins and compositional heterogeneity of bovine milk fat globule membrane. J. Dairy Sci. 60:394-402.

McPherson, A. V., M. C. Dash, and B. J. Kitchen. 1984. Isolation of bovine milk fat globule membrane material from cream without prior removal of caseins and whey proteins. J. Dairy Res. 51:113121.

McPherson, A. V., and B. J. Kitchen. 1983. Reviews of the progress of dairy science: The bovine milk fat globule membrane-Its formation, composition, structure and behavior in milk and dairy products. J. Dairy Res. 50:107-133.

Mondy, B. L., and T. W. Keenan. 1993. Butyrophilin and xanthine oxidase occur in constant molar proportions in milk lipid globule membrane but vary in amount with breed and stage of lactation. Protoplasma 117:32-36.

Morin, P. M. Britten, R. Jiménez-Flores, and Y. Pouliot. 2007. Microfiltration of buttermilk and washed cream buttermilk for concentration of milk fat globule membrane components. J. Dairy Sci. 90:2132-2140.

Nejjar, Y., D. Pâquet, G. Godbillon, and J. Y. L. Deaut. 1986. Immunological relationship between the hydrophobic fraction of proteose-peptone and the milk fat globule membrane of bovine milk. Int. J. Biochem. 18:893-900.

Nielsen, C. S., and O. J. Bjerrum. 1977. Crossed immunoelectrophoresis of bovine milk fat globule membrane protein solubilized with nonionic detergent. Biochim. Biophys. Acta 466:496-509.

Roesch, R. R., A. Rincon, and M. Corredig. 2004. Emulsifying properties of fractions prepared from commercial buttermilk by microfiltration. J. Dairy Sci. 87:4080-4087.

Rombaut, R., J. V. Camp, and K. Dewettinck. 2005. Analysis of phospho- and sphingolipids in dairy products by a new HPLC method. J. Dairy Sci. 88:482-488.

Rombaut, R., J. V. Camp, and K. Dewettinck. 2006. Phospho- and sphingolipid distribution during processing of milk, butter and whey. Int. J. Food Sci. Technol. 41:435-443.

Singh, H. 2006. The milk fat globule membrane-A biophysical system for food applications. Curr. Opin. Colloid Interface Sci. 11:154163

Sorensen, E. S., L. K. Rasmussen, L. Moller, and T. E. Petersen. 1997. The localization and multimeric nature of component PP3 in bovine milk: Purification and characterization of PP3 from caprine and ovine milks. J. Dairy Sci. 80:3176-3181.

Walstra, P. 1985. Some comments on the isolation of fat globule membrane material. J. Dairy Res. 52:309-312.

Walstra, P., J. T. M. Wouters, and T. J. Geurts. 2006. Dairy Science and Technology. 2nd ed. CRC Press, Boca Raton, FL.

Whitney, R. M. 1999. Proteins of milk. Pages 84-169 in Fundamentals of Dairy Chemistry. 3rd ed. N. P. Wong, R. Jenness, M. Keeney, and E. H. Marth, ed. Aspen Publishers, Frederick, MD.

Wiking, L., L. Björck, and J. H. Nielsen. 2003. Influence of feed composition on stability of fat globules during pumping of raw milk. Int. Dairy J. 13:797-803.

Wong, P. Y. Y., and D. D. Kitts. 2003. A comparison of the buttermilk solids functional properties to nonfat dried milk, soy protein isolate, dried egg white, and egg yolk powders. J. Dairy Sci. 86:746-754.

Ye, A., S. G. Anema, and H. Singh. 2004a. High-pressure-induced interactions between milk fat globule membrane proteins and skim milk proteins in whole milk. J. Dairy Sci. 87:4013-4022.

Ye, A., H. Singh, M. W. Taylor, and S. Anema. 2002. Characterization of protein components of natural and heat-treated milk fat globule membranes. Int. Dairy J. 12:393-402.

Ye, A., H. Singh, M. W. Taylor, and S. Anema. 2004b. Interactions of whey proteins with milk fat globule membrane proteins during heat treatment of whole milk. Lait 84:269-283. 